日臨外会誌 $80 （ 3) ， 545-550 ， 2019$

症例

\title{
S 状結腸憩室炎による結腸子宮瘻および子宮留膿腫の 3 例
}

\author{
深谷赤十字病院外科

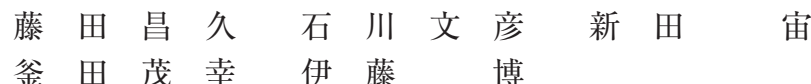

症例 1 は61歳の女性, 腹痛で受診した. CT 検查で $\mathrm{S}$ 状結腸は子宮と近接し, S 状結 腸悡室と子宮内ガスを認め, S 状結腸㮩室炎による結腸子宮瘦と診断し, S 状結腸切除 を行った. 症例 2 は81歳の女性, 膿性帯下で前医を受診. 子宮留膿腫の診断で経臸ドレ ナージを行った後, 貧血精査目的に紹介となった．CT検査で子宮内にガスを含む液体 貯留を, 注腸でS状結腸悡室と造影剤の腸管外流出を認め, S 状結腸悡室炎による結腸 子宮瘦から生じた子宮留膿腫と診断し, S 状結腸切除と瘦孔縫合閉鎖を行った。症例 3 は85歳の女性, 腹痛で受診した. CT 検査で遊離ガス・S 状結腸悡室・骨盤内膿瘍を認め, $\mathrm{S}$ 状結腸悡室穿孔と診断したが, 手術所見は S 状結腸悡室炎による結腸子宮瘦から生じ た子宮留膿腫穿孔であり, S 状結腸切除と子宮両側付属器切除を行った. 大腸㕰室炎に よる結腸子宮瘦は極めてまれであり，大腸悡室炎による結腸子宮㾇から生じた子宮留膿 腫の報告は本邦で初めてである.

索引用語：大腸㮩室, 瘦孔形成, 子宮穿孔

\section{緒言}

近年増加している大腸憩室症であるが, その合併症 の中で㾇孔形成するものは比較的少なく, 特に結腸子 宮瘦は極めてまれである112)。 。た, 大腸㮩室炎に起 因する子宮留膿腫も極めてまれであり, 本邦では過去 2 例しか報告がない334). 今回われわれは, S 状結腸憩 室炎による結腸子宮㿉 3 例を診療する機会に遭遇し, うち 2 例に子宮留膿腫が併発し，1例は子宮留膿腫穿 孔をきたした貴重な症例を経験したので報告する.

症例

症例 $1: 61$ 歳, 女性.

主訴 : 腹痛.

既往歴：高血圧，帝王切開.

現病歴： 2 力月前より左下腹部痛があり, 当院を受 診した

入院時現症：身長 $152 \mathrm{~cm}$, 体重 $65 \mathrm{~kg}$, 体温 $37.4^{\circ} \mathrm{C}$, 血圧 $122 / 72 \mathrm{mmHg}$, 脈拍 88 回/分, 左下腹部に圧痛を 認めたが, 腫瘤は触知しなかった.

2018年 8 月13日受付 2018年12月19日採用

〈所属施設住所〉

干366-0052 深谷市上柴町西 5-8 - 1
血液生化学所見 : 白血球数 $11,200 / \mu 1, \mathrm{CRP} 1.40 \mathrm{mg} / \mathrm{dl}$ と炎症反応の軽度上昇を認めた.

腹部CT検査所見：S状結腸と子宮は近接し，境界 が不明瞭であり，S状結腸に喤室と壁肥厚を，子宮内 にガス像を認めた（Fig. 1A，B）。

注腸造影所見 : S 状結腸に喤室と狭窄を認めたが, S 状結腸と子宮の交通は確認できなかった.

下部消化管内視鏡所見 : S 状結腸に喤室を認め, 粘 膜は浮腫状で狭窄が強く，スコープは通過できなかっ た。㾇孔や腫瘍は認めなかった。

以上より $\mathrm{S}$ 状結腸擤室炎による結腸子宮瘦と診断 し，待機手術を行った。

手術所見 : S 状結腸と子宮頸部後壁の強固な癒着を 剥離し, S 状結腸切除と一期的吻合を行った。剥離時 に子宮側の瘦孔は確認できなかった.

切除標本および病理組織学的所見 : S 状結腸に喤室 の穿孔を認め, 穿孔部周囲には炎症細胞浸潤と膿瘍を 認めた (Fig. 1C).

術後真菌血症を併発したが, 術後16日目に退院した。

症例 $2: 81$ 歳, 女性.

主訴：膿性帯下.

既往歴 : 慢性関節リウマチ, 大腸憩室出血. 

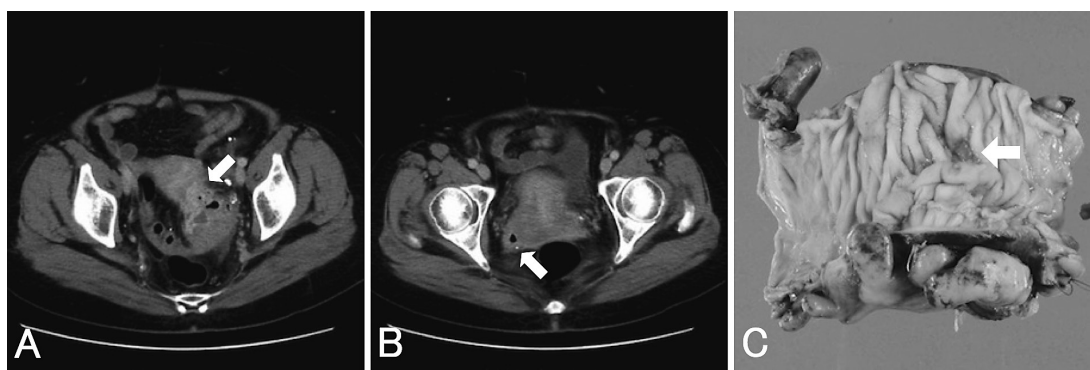

Fig. 1 症例 1

（A）腹部 CT 検査 : S 状結腸と子宮は境界が不明瞭であり（矢印）, S 状結腸に憩室と 壁肥厚を認める.

(B) 腹部 CT 検査 : 子宮内にガス像を認める (矢印).

（C）切除標本 (粘膜面)：S 状結腸に憩室の穿孔を認める (矢印).
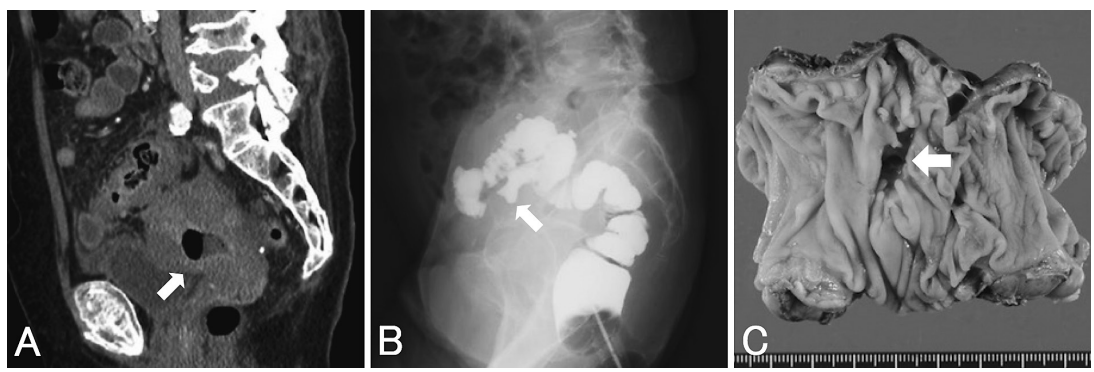

Fig. 2 症例 2
（A）腹部 CT 検査：S 状結腸に鄎室と壁肥厚を，子宮内にガス像を伴う液体の貯留を認 める (矢印).
（B）注腸造影検査：S状結腸に憩室と造影剤の腸管外流出を認める（矢印）.
（C）切除標本 (粘膜面): S 状結腸に憩室の穿孔を認める (矢印).

現病歴：1 カ月前に膿性帯下があり婦人科を受診, 子宮留膿腫の診断で経臸ドレナージを行ったが, 貧血 が進行したため当院紹介となった。

入院時現症: 身長 $136 \mathrm{~cm}$, 体重 $39 \mathrm{~kg}$, 体温 $36.2^{\circ} \mathrm{C}$, 血圧 $118 / 57 \mathrm{mmHg}$, 脈拍 100 回/分, 腹部所見はなく, 直腸診で下血や腫瘤を認めなかった。

血液生化学所見 : Hb $4.7 \mathrm{~g} / \mathrm{dl}$ と高度の貧血を認め, 白血球数 $16,300 / \mu \mathrm{l}, \mathrm{CRP} 7.88 \mathrm{mg} / \mathrm{dl}$ と炎症反応の上 昇を認めた。

腹部 CT 検査所見: S 状結腸と子宮は近接し, S 状 結腸に憩室と壁肥厚を, 子宮内にガス像を伴う液体の 貯留を認めた（Fig. 2A).

注腸造影所見 : S 状結腸に喤室と造影剤の腸管外流 出を認めた (Fig. 2B).

下部消化管内視鏡所見：S状結腸に憩室を認め, 粘 膜は浮腫状で狭窄が強く, スコープは通過できなかっ
た. 㾇孔や腫瘍は認めなかった.

以上より $\mathrm{S}$ 状結腸憩室炎による結腸子宮㾇から生じ た子宮留膿腫と診断し, 待機手術を行った。

手術所見 : S 状結腸と子宮底部の強固な癒着を剥離 し, S 状結腸切除と一期的吻合を行った. 剥離時に子 宮側の瘻孔を確認し, 縫合閉鎖した.

切除標本および病理組織学的所見 : S 状結腸に喤室 の穿孔を認め, 穿孔部周囲には炎症細胞浸潤と線維化 を認めた（Fig. 2C）.

術後経過は良好であり，術後15日目に退院した。術 後 3 年を経過したが, 子宮留膿腫の再発は認めていな い.

症例 $3: 85$ 歳, 女性.

主訴: 腹痛.

既往歴：高血圧, 高尿酸血症, 虫垂炎術後, 大腸憩 室出血. 

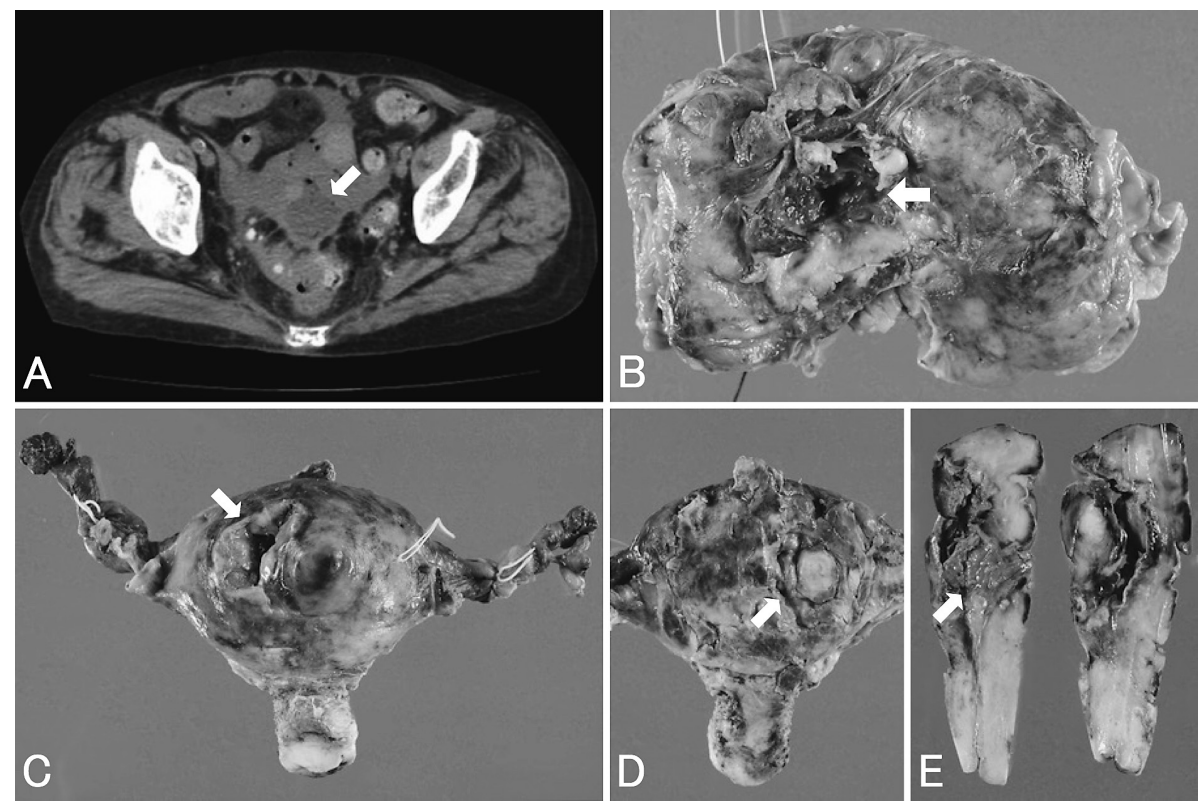

Fig. 3 症例 3

（A）腹部CT検査：遊離ガス像，S 状結腸想室および骨盤内にガス像を伴う膿瘍（子宮留膿腫） を認める (矢印).

（B）切除標本 (漿膜面)：S状結腸に鄎室の穿孔を認める (矢印).

（C）切除標本 (子宮前面）：子宮体部前壁に穿孔を認める (矢印).

（D）切除標本（子宮後面）：子宮体部後壁に穿孔を認める（矢印）.

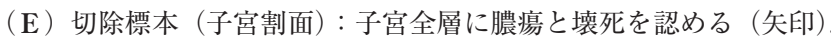

現病歴：数日前より下腹部痛があり, 当日腹痛が増 強したため内科を受診し, 消化管穿孔の診断となり当 院紹介となった。

入院時現症：身長 $151 \mathrm{~cm}$, 体重 $46 \mathrm{~kg}$, 体温 $36.2^{\circ} \mathrm{C}$, 血圧130/54mmHg, 脈拍103回/分, 下腹部に圧痛を 認めたが, 腹膜刺激症状はなかった.

血液生化学検査所見 : 白血球数 $6,500 / \mu 1$, CRP 26.48 $\mathrm{mg} / \mathrm{dl}$ と炎症反応の上昇を認めた.

腹部 CT 検査所見 : 腹腔内に遊離ガス像を, $\mathrm{S}$ 状結 腸に悡室と壁肥厚を, 骨盤内にガス像を伴う膿瘍 (retrospectiveに検討すると子宮留膿腫) を認めた (Fig. 3A).

以上より膿瘍を伴う S 状結腸擤室穿孔と診断し, 緊 急手術を行った.

手術所見 : 化膿性沉発性腹膜炎の状態であり, 子宮 体部前壁に穿孔を認めた. 子宮後壁と S 状結腸は膿瘍 を介して強固に癒着し, S 状結腸は炎症性に肥厚して いた。 以上より S 状結腸悡室炎による結腸子宮瘦から 生じた子宮留膿腫穿孔と診断し, S 状結腸切除, S 状
結腸人工肚門造設および子宮両側付属器切除を行っ た。

切除標本および病理組織学的所見: S 状結腸に䄸室 の穿孔を認め, 穿孔部周囲には膿瘍を認めた（Fig. 3B). 子宮体部の前後壁に穿孔を認め, 全層に膿瘍と 壞死を認めた (Fig. 3C, D, E). 両側付属器に異常 はなかった，術後創感染と脳梗塞を併発したが, 術後 48日目に退院した。

\section{考察}

欧米における大腸悡室症の手術症例の中で瘦孔の占 める割合は $20 \%$ 前後であるが, 瘦孔症例の中で結腸子 宮瘦の占める割合は $1 \sim 3 \%$ と同じ骨盤内臟器である 結腸膀胱瘦の $53 \sim 65 \%$ と比べて極めて少ない122). 憩 室炎により結腸と子宮が癒着し，結腸の炎症が子宮に 波及して子宮筇層内に膿瘍が形成され, 膿瘍が子宮内 腔に穿破して瘦孔は形成されるが，子宮は筋層が厚く 炎症が波及しにくいため, 瘦孔ができにくい. 1981年 〜2017年の期間で「結腸子宮瘦」をキーワードに医学 中央雑誌で検索すると, 本邦における大腸悡室炎によ 
Table 1 大腸憩室炎による結腸子宮瘻および子宮留膿腫の本邦報告例

\begin{tabular}{|c|c|c|c|c|c|c|}
\hline 報告者 & 報告年 & 合併症 & 年齢 & 開腹歴 & 瘦孔部位 & 手術術式 \\
\hline 石黒5) & 1981 & 結腸子宮瘦 & 71 & 無 & 子宮体部 & $\begin{array}{l}\text { S状結腸切除 } \\
\text { 子宮付属器切除 }\end{array}$ \\
\hline 江崎6) & 1996 & 結腸子宮瘻 & 81 & 無 & 子宮体部 & $\begin{array}{l}\text { S状結腸切除 } \\
\text { 瘦孔閉鎖 }\end{array}$ \\
\hline 西7) & 1997 & 結腸子宮瘦 & 78 & 無 & 子宮底部 & $\begin{array}{l}\text { S状結腸切除 } \\
\text { 子宮付属器切除 }\end{array}$ \\
\hline 古川 ${ }^{8)}$ & 2002 & 結腸子宮瘻 & 69 & 胆囊摘出 & 子宮頸部 & $\begin{array}{l}\text { S状結腸切除 } \\
\text { 子宮付属器切除 }\end{array}$ \\
\hline 関根9) & 2006 & 結腸子宮瘦 & 81 & 無 & 子宮 & 人工肛門造設 \\
\hline 福枝10) & 2007 & 結腸子宮瘻 & 72 & 無 & 子宮体部 & $\begin{array}{l}\mathrm{S} \text { 状結腸切除 } \\
\text { 子宮付属器切除 }\end{array}$ \\
\hline 福枝10) & 2007 & 結腸子宮瘦 & 75 & 無 & 子宮頸部 & $\begin{array}{l}\mathrm{S} \text { 状結腸切除 } \\
\text { 子宮付属器切除 }\end{array}$ \\
\hline 田中 ${ }^{3)}$ & 2009 & $\begin{array}{l}\text { 結腸卵管瘻 } \\
\text { 子宮留膿腫穿孔 }\end{array}$ & 79 & 虫垂切除 & 左卵管 & $\begin{array}{l}\text { Hartmann 手術 } \\
\text { 子宮付属器切除 }\end{array}$ \\
\hline 横山4) & 2016 & $\begin{array}{l}\text { 結腸卵管瘻 } \\
\text { 子宮留膿腫 }\end{array}$ & 77 & 無 & 左卵管 & $\begin{array}{l}\text { S状結腸切除 } \\
\text { 子宮付属器切除 }\end{array}$ \\
\hline 大野11) & 2016 & 結腸子宮瘻 & 80 & 虫垂切除 & 子宮底部 & $\begin{array}{l}\text { S状結腸切除 } \\
\text { 子宮摘出 }\end{array}$ \\
\hline Arakawa ${ }^{12)}$ & 2017 & 結腸子宮瘻 & 74 & 無 & 子宮 & $\begin{array}{l}\mathrm{S} \text { 状結腸切除 } \\
\text { 子宮摘出 }\end{array}$ \\
\hline 自験例 1 & 2019 & 結腸子宮瘻 & 61 & 帝王切開 & 子宮頸部 & S 状結腸切除 \\
\hline 自験例 2 & 2019 & $\begin{array}{l}\text { 結腸子宮瘻 } \\
\text { 子宮留膿腫 }\end{array}$ & 81 & 無 & 子宮底部 & $\begin{array}{l}\text { S状結腸切除 } \\
\text { 瘦孔閉鎖 }\end{array}$ \\
\hline 自験例 3 & 2019 & $\begin{array}{l}\text { 結腸子宮瘦 } \\
\text { 子宮留膿腫穿孔 }\end{array}$ & 85 & 虫垂切除 & 子宮体部 & $\begin{array}{l}\text { Hartmann 手術 } \\
\text { 子宮付属器切除 }\end{array}$ \\
\hline
\end{tabular}

る結腸子宮瘦は 9 例の報告があった $(\text { Table 1 })^{5) \sim 12) . ~}$ 結腸子宮瘦は閉経後に多く，本邦報告例の年齢も 69-81歳（平均75.7歳）と高齢であり，加歯による子 宮の萎縮が瘦孔形成の一因と思われるが，子宮側の瘻 孔部位は底部 2 , 体部 3 , 頸部 2 , 不明 2 と一定の傾 向はなく，自験例も各々 1 例ずつであった，大腸憩室 炎による結腸皮膚㾞は手術創部と，結腸腔㾇は子宮摘 出後の腔断端と㿉孔を形成することが多い. 自験例 1 は61歳と本邦報告例で最も若く帝王切開の既往歴があ ったが，瘻孔部位は子宮頸部後壁であり，瘦孔形成と 帝王切開の関連性は指摘できなかった。 また，自験例 2,3 および本邦報告例には子宮の手術歴を認めなか った。

子宮留膿腫は子宮頸管の狭窄により子宮内分泌物の 排出が障害され, 細菌感染をきたして子宮内に膿や壊
死物質が貯留する疾患であり，閉経後の高齢者に好発 する. 1981年〜2017年の期間で「憩室，子宮留膿腫」 をキーワードに医学中央雑誌で検索すると，本邦にお ける大腸憩室炎に起因する子宮留膿腫の報告は 2 例の みであり，いずれも大腸憩室炎による結腸卵管瘻を介 した子宮留膿腫であった $(\text { Table 1 })^{3) 4)}$. 自験例は 2 例とも本邦で初めての報告となる大腸㕰室炎による結 腸子宮瘻から生じた子宮留膿腫であり，81歳，85歳と 本邦報告例で最も高齢であったが，左側大腸憩室炎， 子宮萎縮および子宮頸管狭窄と高齢女性に生じやすい 病態が重なったことが発症の誘因と思われた。自験例 2 は膿性帯下が初発症状であり, 子宮留膿腫の治療を 先行できたが, 自験例 3 では帯下がなく, 腹痛が出現 した数日後に子宮留膿腫穿孔で発症した。 子宮留膿腫 のうち子宮穿孔をきたすものは $5 \%$ と少ないが13)14), 
自験例のように大腸憩室炎による結腸子宮㾇から子宮 留膿腫が生じる場合は, 持続的に污染物質が子宮内に 供給されるため, 子宮内圧の上昇が増強し, 子宮穿孔 をきたす危険性が高くなる可能性がある.

大腸憩室炎による結腸子宮瘦が保存的治療で改善し た報告はなく，本邦報告 9 例全てで手術が施行されて おり，1 例は人工肛門造設のみであったが，他の 8 例 では結腸切除が行われ, うち 7 例で子宮摘出も併施さ れていた. 自験例では子宮穿孔例に対しては子宮摘出 を行ったが, 非穿孔例では瘦孔の縫合閉鎖以外に子宮 への外科的処置を加えず，術後経過は良好であった。 大腸憩室炎による結腸膀胱㾇の術式に関して結腸切除 は必要だが, 膀胱部分切除は不要なことが多いとする 報告があり ${ }^{15)}$, 大腸憩室炎による結腸子宮瘻でも子宮 摘出は必ずしも必要ではないと思われる. 子宮留膿腫 の治療は抗菌薬の投与と経臸的な子宮頸管拡張による ドレナージである. 自験例 2 は前医での頸管拡張ドレ ナージにより自然排膿が期待できる状態であり, 結腸 切除により感染の供給源がなくなれば子宮留膿腫再発 の可能性は低いと判断し, 子宮摘出を行わなかった. 松井ら ${ }^{16)}$ は子宮留膿腫穿孔例でも子宮温存は可能だと 述べているが, 自験例 3 のように結腸子宮瘻と子宮留 膿腫穿孔を併発し，術前に悪性疾患を否定できていな い場合には子宮摘出も行うことが望ましいと思われ る.

\section{結語}

大腸憩室炎による結腸子宮瘻および子宮留膿腫の 3 例を経験した．大腸憩室炎による結腸子宮瘦から生じ た子宮留膿腫の報告は本邦で初めてであり, 閉経後の 高齢者に発症する可能性がある。治療には手術が必要 であるが, 子宮摘出は必ずしも必要ではない.

利益相反：なし

\section{文献}

1) Colcock BP, Stahmann FD : Fistulas complicating diverticular disease of the sigmoid colon. Ann Surg 1972; $175: 838-846$

2) Woods RJ, Lavery IC, Fazio VW, et al : Internal fistulas in diverticular disease. Dis Colon Rectum $1988 ; 31: 591-596$

3）田中浩司, 中村浩志, 桑原 博他：S 状結腸憩室 炎に起因すると考えられた子宮留膿腫穿孔による 沉発性腹膜炎の 1 例. 日消外会誌 2009；42：
$1743-1747$

4）横山真也, 上松俊夫, 鈴木秀昭他：子宮留膿腫を 合併したS状結腸憩室炎の 1 例. 日臨外会誌 2016； 77 : $1166-1170$

5）石黒信彦, 小坂健夫, 上野桂一他：結腸子宮瘦を 合併した結腸㮩室症. 外科診療 $1981 ； 23: 503$ $-506$

6）江崎 敬, 渡辺健志, 高梨裕子他 : 子宮体部穿孔を 伴った大腸喤室症の 1 例. 日産婦東京会誌 1996 ； $45: 153-155$

7）西 敏夫, 大島 聡, 川崎勝弘他 : 結腸㕰室炎に 起因したS状結腸子宮㾇の 1 例. 日臨外会誌 1997 ; $58: 156-159$

8）古川祐介, 中山伸一, 河田光弘他：憩室炎に起因 したS 状結腸子宮㾇の 1 例. 日消外会誌 2002 ; $35: 209-213$

9）関根 理, 山本 宏, 篠原浩一 : 結腸㮩室炎に起 因したS 状結腸子宮㾇の 1 例. 自治医大紀 2006 ; $29: 201-207$

10）福枝幹雄, 牧尾善幸, 渋谷 寛他: S 状結腸想室 症に起因した結腸子宮瘦の 2 例. 日臨外会誌 $2007 ; 68: 1202-1205$

11）大野吏輝, 發知将規, 長橋美弥他 : 腹腔鏡下に子 宮合併 S 状結腸切除を施行した結腸頽室炎に伴う 結腸子宮瘦の 1 例. 日内視鏡外会誌 $2016 ； 21$ ： $221-227$

12) Arakawa S, Morise Z, Isetani M, et al : Laparoscopic sigmoidectomy combined with uterus excision for colouterine fistula caused by sigmoid colon diverticulitis : A case report. Asian J Endosc Surg $2017 ; 10$ : 415-419

13）江口武志, 杉山和歌菜, 小古山学他 : 当院で経験 した子宮留膿腫破裂の検討. 現代産婦人科 2014 ； $63: 147-151$

14) Muram D, Drouin P, Thompson FE, et al : Pyometra. Can Med Assoc J 1981 ; 125 : $589-592$

15）藤田昌久, 幸田圭史：憩室炎による結腸膀胱瘦症 例の臨床的検討. 日本大腸肛門病会誌 2014 ； $67: 442-447$

16）松井俊樹, 野村浩史, 加藤弘幸他：子宮留膿腫の 穿孔部が閉塞点となった機械性腸閉塞の 1 例一子 宮留膿腫穿孔に対する治療術式の検討. 日外科系 連会誌 $2015 ； 40 ： 988-993$ 


\title{
COLOUTERINE FISTULA AND PYOMETRA CAUSED BY DIVERTICULITIS OF THE SIGMOID COLON-A REPORT OF THREE CASES-
}

\author{
Yoshihisa FUJITA, Fumihiko ISHIKAWA, Hiroshi NITTA, \\ Shigeyuki KAMATA and Hiroshi ITO \\ Department of Surgery, Fukaya Red Cross Hospital
}

Case 1: A 61-year-old woman presented with abdominal pain. Computed tomography (CT) showed an unclear boundary between the sigmoid colon with diverticula and the uterus, as well as gas in the uterus. The patient was diagnosed with a colouterine fistula caused by diverticulitis and underwent sigmoidectomy. Case 2: An 81-year-old woman with anemia presented following vaginal drainage with pyometra. CT showed fluid collection with gas in the uterus. Barium enema showed diverticula of the sigmoid colon and outflow of barium from the colon. The patient was diagnosed to have pyometra due to a colouterine fistula caused by diverticulitis and underwent sigmoidectomy with closure of the fistula. Case 3 : An 85-year-old woman presented with abdominal pain. CT showed free air, diverticula of the sigmoid colon, and a pelvic abscess. Suspecting perforation of the sigmoid colon diverticula, surgery was performed. Laparotomy showed perforation of pyometra due to a colouterine fistula caused by diverticulitis. Sigmoidectomy and hysterectomy were then performed. Three extremely rare cases of colouterine fistula and pyometra caused by diverticulitis are described.

Key words : diverticulum, fistula formation, uterine perforation 